\title{
First Report of Black Pod in Tamarind due to Aspergillus niger from India
}

\author{
Chaturbhuj Meena $^{1 *}$, P. Bhatnagar ${ }^{1}$, R.R. Meena ${ }^{2}$, V.C. Prahlad ${ }^{1}$ and Ashok Kumar ${ }^{1}$ \\ ${ }^{1}$ College of Horticulture and Forestry, Jhalrapatan, Jhalawar, Rajasthan-326 023, India \\ ${ }^{2}$ Krishi Vigyan Kendra, Jhalawar, India
}

*Corresponding author

\section{A B S T R A C T}

Keywords

Black Pod,

Aspergillus niger,

Tamarindus indica

Article Info

Accepted:

10 March 2018

Available Online:

10 April 2018
Among Arid Zone Fruits, tamarind, Tamarindus indica L. of the family Leguminosae is a major fruit crop. Survey was conducted to find out major disease of tamarind and found black pod disease was major constraints. Black pod of tamarind incidence was observed range from 8.00 -22 per cent in pod on tree and incidence in storage was observed 5-22.5 per cent at different location in Jhalawar district during 2013 to 2017. Subsequently, the pathogen was isolated and pure culture of fungus established. The pathogenicity of fungus was proved and it was identified as Aspergillus niger by Indian Type Culture Collection, Division of Plant Pathology, Indian Agricultural Research Institute, New Delhi.

\section{Introduction}

Tamarind native to tropical Africa, the tree grows wild throughout the Sudan and was so long ago introduced into and adopted in India that it has often been reported as indigenous there also, and it was speciously from this Asiatic country that it reached the Persians and the Arabs who called it "tamar hindi" (Indian date, from the date-like appearance of the dried pulp), giving rise to both its common and generic names. Unfortunately, the specific name, "indica", also perpetuates the illusion of Indian origin. Of all the fruit trees of the arid zone fruit, none is more widely distributed nor more appreciated as an ornamental than the tamarind, Tamarindus indica L. of the family
Leguminosae. Tamarind is a slow-growing, long-lived, massive tree reaches, under favorable conditions, a height of 80 or even $100 \mathrm{ft}(24-30 \mathrm{~m})$, and may attain a spread of $40 \mathrm{ft}(12 \mathrm{~m})$ and a trunk circumference of $25 \mathrm{ft}$ $(7.5 \mathrm{~m})$. It is highly wind-resistant, with strong, supple branches, gracefully drooping at the ends, and has dark-gray, rough, fissured bark (Karale, 2006; Dilip Babu and Saroj 2018). Several diseases have been reported to infect tamarind in India, including various tree rot and bacterial leaf spot. The major disease reported are leaf spot (Bartalinia robillardoides, Tassi., Exosporium tamarindi Syd., Hendersonia tamarindi Syd., Pestalotia poonensis V. Rao., Phyllosticta tamarindicola $P$. tamarinedina Chandra and Tandon, 
Prathigada, tamarindi Muthappa, Xanthomonas tamarind Cook., Sphaceloma spp. and Stigmina tamarindi (Syd.) Munjal and Kulshrestha, powdery mildew (Erysiphe polygoni DC and Oidium spp.), sooty mould (Meliola tamarindi Syd.), stem disease (Fracchiaea indica Talde), whit rot and wood rot (Ganoderma lucidum (leyss) Karst Lenziles Pliosti Fr.), stem rot (Pholiota gollani P. Henn), trunk or root rot (Stereum nitidulum Berk.), collar rot (Phytophthora nocitianae var. nicotianae); (Siddaramiah et al., 1980), stem canker (Hypoxlon nectrioides Speg) (Mukherji and Bhasin, 1986; Siddaramiah and Kulkarni,1982; Morton, 1987; Parrotta, 1990), stony fruit Pestalotia macrotricha syd. (Lokesha and Shetty, 1991). Rots attacking the tree include sap rot, Xylaria euglossa, brownish sap rot, Polyporus calcuttensis, and white rot, Trametes floccose, powdery mildew Erysiphe polygoni. Present survey was conducted to find out the major disease of tamarind in Rajasthan under All India Coordinated Research Project on Arid Zone Fruit at College of Horticulture and Forestry, Jhalawar Rajasthan.

\section{Materials and Methods}

A survey was conducted during 2013 to 2017 for disease of tamarind at different location (Table 1 and 2) in Jhalawar district and sample of tamarind pod collected from stored tamarind pod by the farmers and pod on tree at different location in Jhalawar district. The pathogen was isolated from infected pod and purified using standard procedure.

\section{Results and Discussion}

Survey results revealed that diseases like leaf spot, powdery mildew and black pod observed in tamarind at different location in Jhalawar Rajasthan. Among the disease observed black pod was major constraints and its incidence was range from $8.00-22$ per cent at different location on tree (Table 1 and Figure 1) and in storage the incidence was observed 5-22.5 per cent at different location (Table 2 and Figure 2). Subsequently, the pathogen was isolated and pure culture of fungus established (Figure 3 ) and pathogenicity of fungus was proved. The Sporulating sections of black pod were removed and single-spore isolations were made on potato dextrose agar (PDA) medium. The single spore isolates developed into a compact white basal mycelium covered with a dense layer of conidiophores (Figure 4) covered with dark brown to black spores (Figure 5). The vesicles of the conidiophores were large and globose. The conidiophores were smooth-walled, hyaline with vesicle. Black pod of tamarind pathogen was identified as Aspergillus niger (Figure 4 and 5) by Indian Type Culture Collection (ITCC), Division of Plant Pathology, Indian Agricultural Research Institute, New Delhi.

Table.1 Incidence of black pod in tamarind on tree

\begin{tabular}{|c|c|c|}
\hline Year & Per cent Incidence & Location \\
\hline \multirow{2}{*}{$\mathbf{2 0 1 6}$} & 18.00 & Dityakheri, Jhalrapatan \\
\hline & 22.00 & Motipura Jhalrapatan \\
\hline \multirow{3}{*}{$\mathbf{2 0 1 7}$} & 13.00 & Urmal Jhalrapatan \\
\hline & 8.00 & Garnavda Bhavani mandi \\
\hline & 17.00 & Motipura Jhalrapatan \\
\hline & 15.00 & Amali Kala Bhuwani mandi \\
\hline & 14.00 & Mishroli, Bhuwani mandi \\
\hline
\end{tabular}


Table.2 Incidence of black pod of tamarind in stored pod

\begin{tabular}{|l|c|l|}
\hline Year & Per cent Incidence & location \\
\hline $\mathbf{2 0 1 3}$ & 22.5 & Ananda Jhalrapatan \\
\hline $\mathbf{2 0 1 4}$ & 5.00 & Kuntara, Khanpur \\
\hline $\mathbf{2 0 1 5}$ & 15.00 & Sarola Kala, Khanpur \\
\hline $\mathbf{2 0 1 6}$ & 6.00 & Borda, Aklera \\
\hline $\mathbf{2 0 1 7}$ & 14.00 & Tharol, Aklera \\
\hline & 19.00 & Amlikala Bhavani Mandi \\
\hline & 18.00 & Mishroli Bhawanimandi \\
\hline & 12.00 & Garnavada Bhawanimandi \\
\hline
\end{tabular}

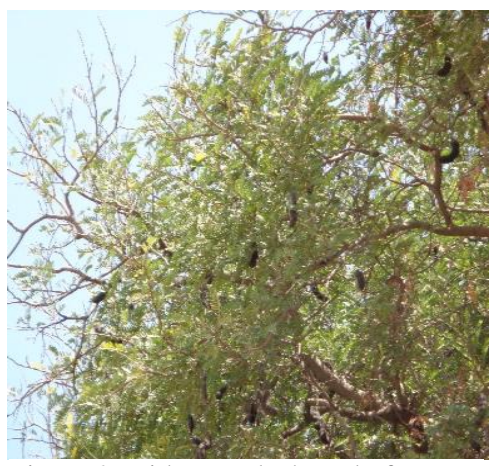

Figure 2Incidence Black Pod of tamarind on tree

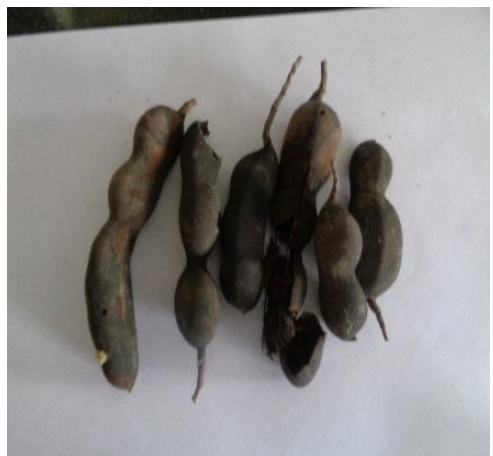

Figure 1Black pod in stored tamarind pod

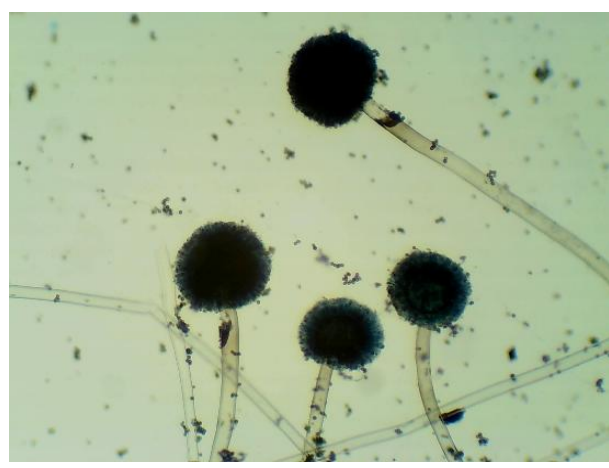

Figure 3Microscopic picture of conidiophore of A. niger

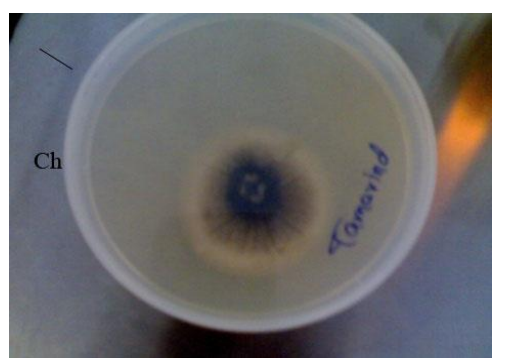

Figure 3Pure Culture of Aspergillus niger isolated from tamarind pod
Similarly, fruit rot caused by Aspergillus niger in lemon was also reported by Liaquat et al., (2016).

\section{Acknowledgement}

The Authors are grateful to the Central Institute Arid Horticulture, Bikaner for providing financial support to conduct this research and required facility provided by

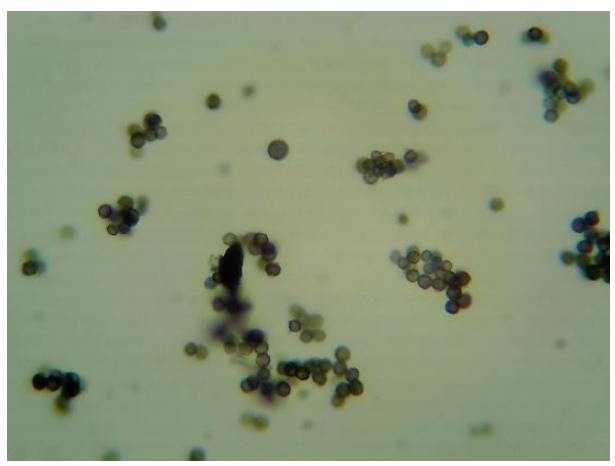

Figure 5 Microscpic picture Conidia of A.niger

Dean CHF, Jhalawar, AU, Kota. We also express our sincere thanks to ITCC, Division of Plant Pathology, IARI, New Delhi for culture Identification.

\section{References}

Dilip Babu, J. and Saroj, P.L. 2018. Tamarind: A Promising Arid Fruit Crop. pp58 
Karale A.R. 2006. Tamarind: Advance in Arid Horticulture. 2: 405-433

Liaquat, F., S. Arif, M. Ashraf, H. J. Chaudhary, and Munis M.F.H. 2016. Aspergillus niger causes Fruit Rot of Lemon and Grapefruit in Pakistan. Plant Disease 100(9):1951 https://doi.org/10.1094/PDIS-02-160199-PDN

Lokesh, S. and Shetty, H.S. 1991. A Pestalotia speces causing stony fruit disease in tamarind. International Journal of Tropical Plant Disease. 9(2): 179-181.

Morton, J., 1987. Fruit of warm climate Miami FL 115-121

Mukherji, K.G. and Bhasin, J., 1986. Plant Disease of India: A Source Book, New Delhi Tata McGraw Hill 468
Parrotta, J.A. 1989. Tamarindus indica L. Tamarind SO-ITF-SM-30, June, USDA, Forestry Service, Rio Piedras, Puerto Rico, 1-5

Siddaramiah, A. 1. and Kulkerni, S. 1982. Control of powdery mildew disease of tamarind seedling. Indian Forester, 108(5):361-364

Siddaramiah, A.L., S.A. Desai, and Bhat, R.P. 1980. A new collar rot of Tamarindus indicus from India (Phytophthora nicotianae var. nicotianae). Science and Culture 44(10): 358-359.

Siddig, K. El. 2006. Tamarind: Tamarindus indica L. https://books.google.co.in/ books? isbn $=0854328599$.

\section{How to cite this article:}

Chaturbhuj Meena, P. Bhatnagar, R.R. Meena, V.C. Prahlad and Ashok Kumar. 2018. First Report of Black Pod in Tamarind due to Aspergillus niger from India. Int.J.Curr.Microbiol.App.Sci. 7(04): 1127-1130. doi: https://doi.org/10.20546/ijcmas.2018.704.123 